\title{
重水素イオン照射されたゲラファイトの熱緩和
}

\author{
浅利栄治* - 中村一隆 ・河辺隆也* · 北島正弘 \\ 金属材料技術研究所－３05つくば市千現 1-2-1 \\ * 外来研究員 (筑波大学物理学系加ら) \\ (1994 年 7 月 4 日受付, 1994 年 9 月 6 日掲載決定)
}

\section{Thermal Relaxation of Graphite under Deuterium Ion Irradiation}

\author{
Eiji Asari*, Kazutaka G. Nakamura, Takaya Kawabe* and Masahiro Kitajima \\ National Research Institute for Metals \\ 1-2-1 Sengen, Tsukuba, Ibaraki 305 \\ * visiting researchers from the University of Tsukuba
}

(Received July 4, 1994 : Accepted September 6, 1994)

\begin{abstract}
Real-time Raman measurements of graphite are performed during and after deuterium ion irradiation at sample temperatures between $353 \mathrm{~K}$ and $473 \mathrm{~K}$. There are two distinct thermal relaxation processes, i.e. fast and slow ones. The activation energy of the fast process is $0.91 \pm 0.15 \mathrm{eV}$ and is comparable with that for helium ion irradiation. The activation energy of the slow process is $0.25 \pm 0.11 \mathrm{eV}$ and is obviously different from that for helium ion irradiation $(1.8 \pm 0.3 \mathrm{eV})$.
\end{abstract}

\section{1.はじめに}

グラファイトはイオン照射を受けるとその物理化学的 な性質が変化する。イオン照射されたグラファイトの構 造乱れやその熱緩和の研究は, グラファイトの層間化合 物 ${ }^{1 \sim 4)}$ やプラズマ核融合炉対向壁材の研究 ${ }^{5,6)}$ 亿関連し て，広く行わ机てきた。

イオン照射グラファイトの構造乱れとその熱緩和につ いて多くの研究が行われてきたにあかかわらず7,8) その 構造変化の過程をその場で測定したものはほとんどな かった。そてで, われわれはグラファイトの構造変化の 過程とその場測定に着目し，イオン照射下における実時 間ラマン分光により, 秒単位の構造乱れの変化の過程に ついて測定を行ってきた ${ }^{9)}$ ，その結果，試料温度が室温 近傍に扔いては, イオン照射中の結晶構造の乱れに起因 したラマンスペクトルのピーク $(D)$ は，照射時間と共 に增加し，グラファイトフォノンの $E_{2 g 2}$ モードに起因 したピーク $(G)$ に対する強度比 $(R)$ は, 照射時間の平 方根に比例して增加することを見出した ${ }^{10,11)}$ 。乙れは, グラファイト面内のフォノンの空間相関距離がイオン照 射により生成された空格子間の近接平均距離に等しいと
考えるモデル (IDD Model) により定量的に説明され た ${ }^{10)}$ 。また，昇温したグラファイト (373〜 $\left.513 \mathrm{~K}\right)$ での $\mathrm{He}$ イオン照射の実験加ら, 結晶構造乱れの緩和過程の 速度を測定し，速度の異なる 2 種類の過程があるととを 明らかにした ${ }^{12,13)}$ 。今回，われわれは昇温した（373〜 $473 \mathrm{~K})$, 重水素イオン照射グラファイトの熱緩和過程の 実時間ラマン測定を行ったので，その結果について報告 する。

\section{2. 実 験}

試料は，結晶性の高い高配向性熱分解黒鉛 (HOPG : Highly Oriented Pyrolytic Graphite : Union Carbide 社製 ZYA）で，サイズは， $12 \times 12 \times 2 \mathrm{~mm}^{3}$ のものを使 用した。グラファイトの表面は, 各測定ごとに粘着テー プ法で剝し, 損傷を受けていない新しい面を出して使用 した。重水素イオン照射は超高真空チャンバー（到達真 空度 $\left.<1 \times 10^{-8} \mathrm{~Pa}\right)$ 内で行い，照射中の真空度は約 $1 \times$ $10^{-6} \mathrm{~Pa}$ であった。イオン加速エネルギーは $5 \mathrm{keV}$ であ り，照射の角度はチャンネリング効果を抑えるため試料 の $c$ - 軸に対して $55^{\circ}$ 亿設定した。イオン流束の值は 2.7 $\times 10^{15} \mathrm{ions} / \mathrm{m}^{2} \mathrm{~s}$ であった。ラマン散乱の励起光には, 連 
続発振のアルゴンイオンレーザー（COHERENT INNOVA 70)の $514.5 \mathrm{~nm}$ の光を $120 \mathrm{~mW}$ の出力で用いた。試 料加熱は， Ni ヒータープレートを用いて行い，試料温 度は試料表面に密着したアルメルクロメル熱電対で測定 した。

ラマン散乱光はチャンバーのサファイア空を通して後 方散乱配置で集光し，ダブルモノクロメーター(JASCO TRS-660) で分光後スペクトロメトリックマルチチャン ネル検出器 [SMA］(プリンストンインスッルメント社 D/SIDA 700) で検出した。ラマンスペクトル測定の時 間分解能は，24〜48 秒であった。ラマンスペクトルは, ローレンツ型線形の重ね合わせにより解析を行った。

イオン照射の時間は 300 秒とした。実験時の試料温度 は373〜 473K に設定した。ラマンスペクトルの測定は， 試料の昇温後一定温度になってから開始し，イオン照射 中および照射終了後に 4700 秒間行った ${ }^{12)}$ 。

\section{3。結果}

Fig. 1 a)〜 e)は, 試料温度 $433 \mathrm{~K}$ における重水素 イオン照射前後のグラファイトの1次のラマンスペクト ルの時間変化の例である。Fig. 1 a) はイオン照射前の ラマンスペクトルである。約 $1580 \mathrm{~cm}^{-1}$ に $E_{2{ }_{2}}$ モード に刘応したピーク $(G)$ のみが観測された。Fig. 1 b) および Fig. 1 c) は，イオン照射開始後 $150 \mathrm{~s}$ およびイ
オン照射終了直後（照射時間 $300 \mathrm{~s}$ ）に測定したスペク トルで, $G$ ピークのほかに約 $1360 \mathrm{~cm}^{-1}$ にグラファイト の結晶構造の乱れに起因するピーク $(D)$ が観測され た。このピークは照射時間の増加に伴いピーク強度が増 加した。これはグラファイトのフォノンの状態密度の極 大に刘応するピークであり，照射損傷の格子乱れによる 波数ベクトルの選択則の緩和により現れるむのである。 Fig. 1 d)とe)は照射を止めて $1000 \mathrm{~s}$ および $4500 \mathrm{~s}$ 後 のラマンスペクトルである。照射停止後 $1000 \mathrm{~s}$ (Fig. 1 d))のものでは, 停止直後 (Fig. 1 c )) と比べて $D$ ピークの減少が認められ顕著な熱緩和を示している。照 射停止後 $4500 \mathrm{~s}$ (Fig. 1e )) の屯のでは, 停止後 1000 s (Fig. 1 d)) と比べて $D$ ピークはほとんど減少して いない。

Fig. 2 a)〜d) は試料温度が 373〜 473 K でのイオ ン照射中と照射後のラマンスペクトルの $G$ ピークに対 する $D$ ピークの強度比 $(R=D / G)$ の時間変化を示した ものである。試料温度 $373 \mathrm{~K}$ では，イオン照射が始まる とRは照射時間の平方根に比例して急激に増加し, 照射 開始より $300 \mathrm{~s}$ 後には約 1.20 まで達する (Fig. 2 a))。 照射終了後において $R$ はほとんど減少しない。Fig. 2 b) は試料温度が $413 \mathrm{~K}$ でのピーク強度比 $R$ の時間変 化である。イオン照射が始まると $R$ は $300 \mathrm{~s}$ で約 1.10 まで増加するが，照射終了後は緩やかに減少する。これ

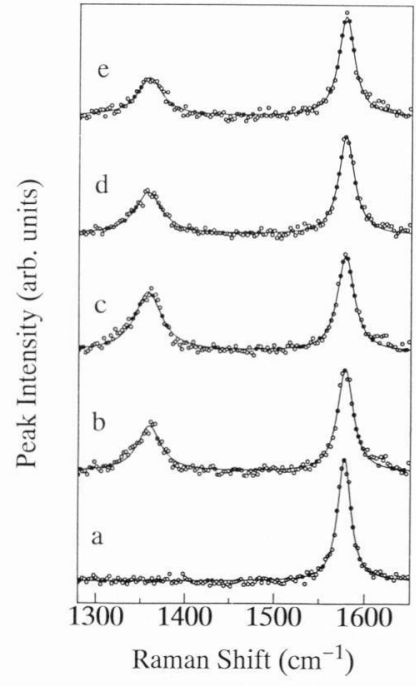

Fig. 1 Raman spectra of HOPG at $453 \mathrm{~K}$ : (a) before ion irradiation, (b) and (c) obtained after $150 \mathrm{~s}$ and $300 \mathrm{~s}$ of $5 \mathrm{keV}$ deuterium ion irradiation at a flux of $2.7 \times 10^{15}$ ions $/ \mathrm{m}^{2} \mathrm{~s}$, respectively, and (d) and (e) respectively obtained at $1000 \mathrm{~s}$ and $4500 \mathrm{~s}$ after the stop of irradiation. Solid lines are obtained by computer simulation.
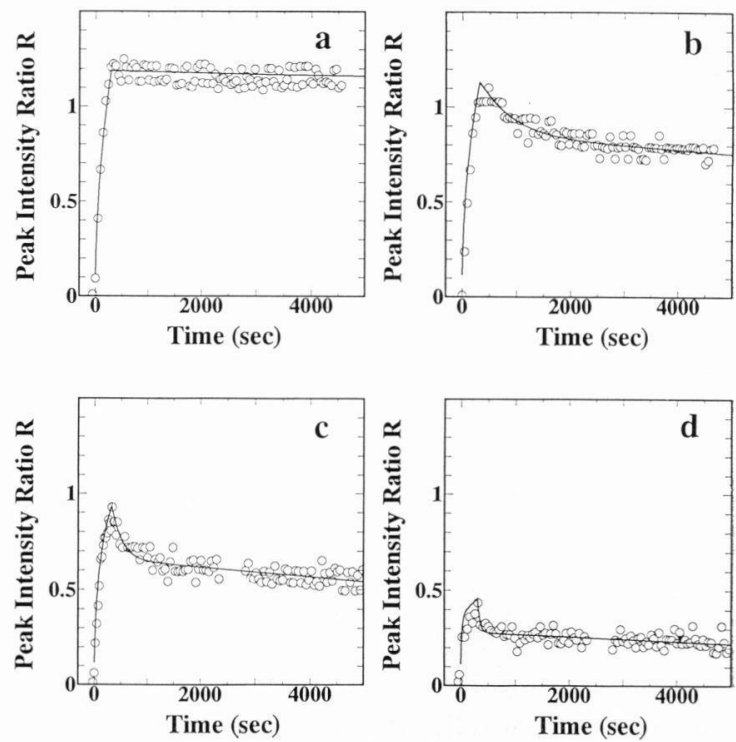

Fig. 2 Time dependence of $R$ for $5 \mathrm{keV}$ deuterium ion irradiation of HOPG at (a ) $373 \mathrm{~K}$, ( b ) $413 \mathrm{~K}$, (c) $433 \mathrm{~K}$ and (d) $473 \mathrm{~K}$. Deuterium ion irradiation was performed in the first $300 \mathrm{~s}$. Solid curves are results of least-squares calculation by Eqs. (4) $(<300 \mathrm{~s})$ and $(5)(>300 \mathrm{~s})$. 
は，イオン照射によって生じた格子乱れが照射後に熱緩 和を起こしているととを示している。Fig. 2 c)は, 試 料温度が $433 \mathrm{~K}$ のときの $R$ の時間変化である。照射終 了時の $R$ の值は約 0.95 であり, 照射終了後約 $200 \mathrm{~s}$ で 0.71 まで急速に減少し, それ以後はゆっくりと減少す る。Fig. 2 d)は, 試料温度が $473 \mathrm{~K}$ のあのである。照 射終了時までに $R$ の值は，0.45 までしか増加しない。 照射終了後の $R$ は $433 \mathrm{~K}$ の場合より速く減少し, 約 0.30 まで下がったところから, 速度の遅い緩和がみられ る。

\section{4. 考察}

1 次のラマンスペクトルの $G$ ピークと $D$ ピークの相 対強度 $R$ は多結晶グラファイトの結晶サイズあるいは 平面内のフォノンの空間相関距離 $L_{a}$ 亿逆比例する ${ }^{14)}$ 。 すなわち,

$$
R=C / L_{a}
$$

である。乙とで, Cは比例定数で $4.4 \mathrm{~nm}$ である。また最 近, Nakamura と Kitajima は, イオン照射初期に生成 されたグラファイトの空格子は結晶の並進対称性を崩し フォノンの伝播を切断するという考えに基づき, 照射に よって生成された空格子間の面内近接平均距離 $L$ 面内 フォノンの空間相関距離によく対応する $\left(L \sim L_{a}\right)$ とをを 理論計算と実験との対応から示した (IDD Model) ${ }^{10,11)}$ 。 すなわち，イオン照射中のグラファイトのピーク強度比 $R$ の増加は, 空格子生成によるフォノンの空間相関距離 の減少を意味し, 照射終了後の $R$ の減少は空格子消隇 によるフォノンの空間相関距離の増加を意味する (Fig. 2 a ) $\sim$ d))。

Fig. 2 c) および d) の照射後の熱緩和過程より, 空 格子の熱緩和には, 速く進行する過程と遅く進行する二 つ過程の存在が示唆される。熱緩和における二つの過程 の存在は, He イオン照射実験においても認められてい る $^{12,13)}$ 。イオン照射により生成された空格子が二つの熱 緩和過程を通して独立に消滅すると考えると, 速い緩和 過程と遅い緩和過程で消滅する空格子密度 $N_{d 1}, N_{d 2}$ の 時間変化はそれぞれ，

$$
\begin{aligned}
& d N_{d 1} / d t=A N \sigma_{d} \nu \phi-\tau_{1} N_{d 1} \\
& d N_{d 2} / d t=(1-A) N \sigma_{d} \nu \psi-\tau_{2} N_{d 2}
\end{aligned}
$$

と書ける ${ }^{12,13)}$ 。乙こで両式の右辺第 1 項は, イオン照射 による空格子の生成項を，第 2 項は，熱緩和による空格 子の消滅項を表わす。ここで $A$ は速い緩和で消滅する 空格子の全空格子に対する割合を示す。Nはグラファイ トの原子数密度, $\sigma_{d}$ ははじき出しの衝突断面積 ${ }^{15)}, \nu$ は 損傷関数 ${ }^{16)}, \phi$ はイオン流密度, $\tau_{1}$ と $\tau_{2}$ は速い緩和と 遅い緩和の時定数を表わす。総空格子数密度 $N_{d}$ は $N_{d 1}$
$+N_{d 2}$ となる。(1)式と (2)，（3)式の解を用いてピー ク強度比 $R$ は, 照射中においては

$$
\begin{aligned}
R= & B\left\{A\left[1-\exp \left(-t / \tau_{1}\right)\right] \tau_{1}\right. \\
& \left.+(1-A)\left[1-\exp \left(-t / \tau_{2}\right)\right] \tau_{2}\right\}^{1 / 2}
\end{aligned}
$$

となり，照射停止後では

$$
\begin{aligned}
R= & B\left\{A\left[1-\exp \left(-t_{0} / \tau_{1}\right)\right] \exp \left[-\left(t-t_{0}\right) / \tau_{1}\right] \tau_{1}\right. \\
& \left.+(1-A)\left[1-\exp \left(-t_{0} / \tau_{2}\right)\right] \exp \left[-\left(t-t_{0}\right) / \tau_{2}\right] \tau_{2}\right\}^{1 / 2}
\end{aligned}
$$

となる。ここで， $t_{0}$ は照射停止時間であり，定数 $B$ は

$$
B \equiv C \sqrt{f N \sigma_{d} \nu \psi}
$$

である。こてで $f$ はグラファイトの面間距離である。緩 和速度 $1 / \tau$ が小さいときは照射中の $R$ は

$$
R=B t^{1 / 2}
$$

で表わされ, $R$ は照射時間の $1 / 2$ 乗に比例して増加する ことが導かれる。

イオン照射によるグラファイトの損傷深さはレーザー の浸入深さより小さいため, 非損傷領域からの影響を補 正する必要がある ${ }^{10)}$ 。モンテ・カルロ計算 (TRIM 89) から求められる損傷分布関数を用い, 光学的吸収関数を 考慮して求めた補正係数は 1.02 となった。乙れは見か け上の $R$ は損傷領域での $R_{0}$ にほとんど一致するとと を意味しているので，乙こでは実測の $R$ の值で議論を 行う。照射されるイオンがすべて $D_{2}{ }^{+}$であると考えて 計算を行うと, (6)式より $B_{\text {cal. }}$ の值は $0.077\left(\mathrm{sec}^{-1 / 2}\right)$ と なる。緩和の小さい室温近傍での実験データから，（7） 式を用いて求められた $B_{\exp }$ は $0.069\left(\mathrm{sec}^{-1 / 2}\right)$ となっ た。データの解析には実験より求められた $B_{\exp }$. を用い Fig. 2 a)〜 d) の実験データに(4),（5)式をフィッ ティングするととによってAおよび $\tau_{1}$ え 2 をそれぞれ の温度について決定した。Fig. 2 a)〜d）の実線は関 数 $R$ の実験值へのフィッティングの結果である。照射 中および照射後においてよく実験值を再現することがわ かる。特に Fig. 2 c), d) の速い緩和過程と遅い緩和過 程の二つの存在をうまく表わしている。

Fig. 3 に, $393 \mathrm{~K}$ 以上でのパラメーター $A$ の值の温 度依存性を示す。 $A$ の值は温度上昇に従い増加する傾向 が認められる。これは, 試料温度が上昇するに従い速い緩 和で消滅する空格子の割合が増加することを意味する。 $\mathrm{He}$ イオン照射の熱緩和において $A$ の值の温度依存性 は顕著でない(12,13)。一つの可能性としててれは，グラ ファイト内の重水素の存在が何らかの形で速い緩和を抑 制し, 温度上昇に伴うグラファイトからの重水素放出量 の増加が，速い緩和の抑制を緩めることが考えられる。

Fig. 4 は, 重水素イオン照射実験の 393〜 473 K で の $R$ の時間変化 $(0 \sim 5000$ 秒 $)$ から求められた緩和速度 $1 / \tau_{1}$ と $1 / \tau_{2}$ の Arrhenius プロットである。比較のため 


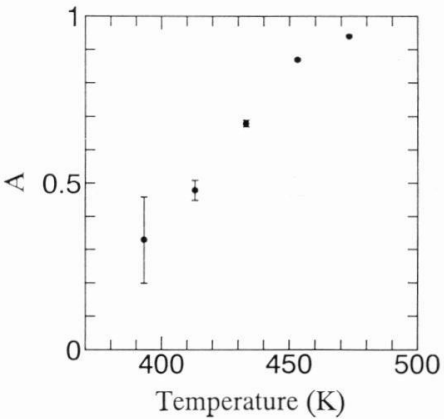

Fig.13 Temperature dependence of parameter $A$, which represents the ratio of the vacancy concerning fast relaxation (I) to the total vacancy.

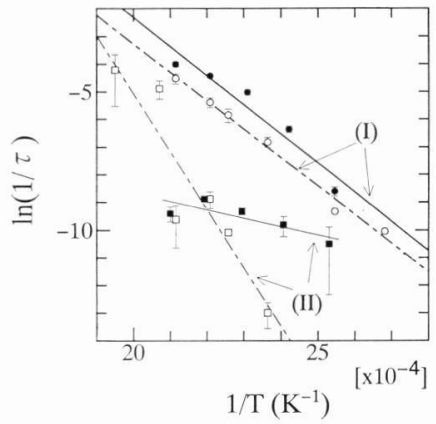

Fig. 4 Arrhenius plot of rate constants $1 / \tau_{1}$ and $1 / \tau_{2}(\boldsymbol{\square})$ for deuterium ion irradiation, and $1 / \tau_{1}(\bigcirc)$ and $1 / \tau_{2}(\square)$ for helium ion irradiation. Activation energies of process (I) and (II) for deuterium ion irradiation are $0.91 \pm$ $15 \mathrm{eV}$ and $0.25 \pm 0.11 \mathrm{eV}$, and those of process (I) and (II) for helium ion irradiation are $0.89 \pm 0.10 \mathrm{eV}$ and $1.8 \pm 0.3 \mathrm{eV}$, respectively. At temperatures of $483 \mathrm{~K}$ and $513 \mathrm{~K}$ for helium ion irradiation experiment, $\tau_{2}$ was determined by annealing method.

$\mathrm{He}$ イオン照射実験のときの屯の屯表示した。グラフの 傾きから速い緩和過程 (I) お おび遅い緩和過程 (II) の活 性化エネルギーは, $0.91 \pm 0.15 \mathrm{eV}, \quad 0.25 \pm 0.11 \mathrm{eV}$ と 見積もられた。速い緩和過程（I）の活性化エネルギー は, He イオンによる熱緩和実験 ${ }^{12,13}$ で観測された過程 （I）の活性化エネルギー $0.89 \pm 0.10 \mathrm{eV}$ 之誤差内で一 致する。

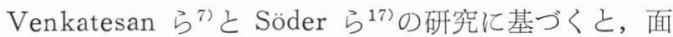
間炭素原子が面間を移動して空格子と再結合するための 活性化エネルギーは約 $0.65 \mathrm{eV}$ となり, この值はラマン スペクトルの測定から求めた速い過程 (I)の值と比較的 近い。今回の重水素イオン照射実験から求めた速い緩和 過程は, Heイオン照射実験のときと同じく, 面間移動す
る炭素原子と空格子との再結合反応によるフォノンの空 間相間距離の増加と考えられる。重水素照射の遅い緩和 過程 (III)の活性化エネルギーは, 乙の実験の温度範囲 では $0.25 \pm 0.11 \mathrm{eV}$ と見積もられ, He イオン照射の值 $1.8 \pm 0.3 \mathrm{eV}$ に比べて小さい。この違いは, 重水素の化 学的効果の可能性が考えられる。遅い過程 (II) 飞ついて は, 緩和速度が遅いため, メカニズムなどの精度の高い 議論を行うためには, より長時間の実験が必要である。

\section{謝 辞}

論文の本原稿を読んでいただき，有意義な指摘之助言 をいただいた石岡博士に感謝いたします。

\section{文献}

1) B. S. Elman, M. S. Dresselhaus, G. Dresselhaus, E. W. Maby and H. Mazurek: Phys. Rev. B 24, 1027 (1981).

2) B. S. Elman, M. Shayegan, M. S. Dresselhaus, H. Mazurek and G. Dresselhaus: Phys. Rev. B 25, 4142 (1982).

3) M. S. Dresselhaus and G. Dresselhaus: "Light Scattering in Solids III" (edited by M. Cardona and G. Guntherodt, Springer, Berlin, 1982) p. 2 .

4) T. Kelly: "Physics of Graphite" (Applied Science, London, 1981).

5) M. Kitajima, K. Aoki and M. Okada: J. Nucl. Mater. 149, 269 (1987).

6) T. Tanabe, S. Muto, Y. Gotoh and K. Niwase: J. Nucl. Mater. 175, 258 (1990).

7) T. Venkatesan, B. S. Elman, G. Braustein, M. S. Dresselhaus and G. Dresselhaus: J. Appl. Phys. 56, 3232 (1984).

8) K. Niwase, T. Tanabe and I. Tanaka : J. Nucl. Mater. 191-194, 335 (1992).

9) K. Nakamura and M. Kitajima: Appl. Phys. Lett. 59, 1550 (1991).

10) K. Nakamura and M. Kitajima: Phys. Rev. B 45, 78 (1992).

11) K. Nakamura and M. Kitajima: Phys. Rev. B 45, 567 (1992).

12）浅利栄治, 北島正弘, 中村一隆, 河辺隆也：表面 科学 14 (5), 301 (1993).

13) E. Asari, M. Kitajima, K. G. Nakamura and T. Kawabe: Phys. Rev. B 47, 11143 (1993).

14) F. Tuinstra and J. L. Koenig: J. Chem. Phys. 53, 1126 (1970).

15) P. Sigmund: "Sputtering by Particle Bombardment I" (edited by R. Behrisch, Springer, Berlin, 1981) p. 9.

16) G. H. Kinchin and R.S. Pease: Rep. Prog. Phys. 18, 1 (1955).

17) B. Söder, J. Roth and W. Moller: Phys. Rev. B 37,815 (1988). 